\title{
AN APPROACH WEB SERVICE SELECTION BY QUALITY CRITERIA BASED ON SENSITIVITY ANALYSIS OF MCDM METHODS
}

Polska O. V. - Senior lecturer of the Department of Computer Systems and Networks, Zaporizhzhia Polytechnic National University, Zaporizhzhia, Ukraine.

Kudermetov R. K. - PhD, Associate Professor, Head of the Department of Computer Systems and Networks, Zaporizhzhia Polytechnic National University, Zaporizhzhia, Ukraine.

Shkarupylo V. V. - PhD, Associate Professor, Associate Professor of the Department of Computer Systems and Networks, National University of Life and Environmental Sciences of Ukraine, Kyiv, Ukraine.

\section{ABSTRACT}

Context. The problem of QoS based Web service from the list of Web services with equal or similar functionality was considered. This task is an essential part of the processes of finding, discover, matching and using Web services on the Internet due to the numerous offerings of Web services with equal or similar functionality. The reasonable selection of a suitable Web service takes into account a lot of user's quality requirements, such as response time, throughput, reliability, cost, etc. Such a task is usually formulated as an MCDM problem, in which the parameters are the Web service quality factors and the importance degree of these factors. The object of this research is a process of selection Web services using MCDM methods, taking into accounts the user's preferences and requirements to the Web service quality characteristics. The subject of the research is the LSP method, which, in addition to the degree of importance of the criteria used in all MCDM methods, simulates the user's reasoning about quality, taking into account, in particular, such characteristics of the criteria as mandatory, sufficiency, desirability, simultaneity and substitutability.

Objective. The objective of the work is to develop an approach for comparing the result of using the LSP method with the results of using other MCDM methods.

Method. A method for calculating the weights of input criteria that are not always explicitly specified in the LSP method was proposed. For this, the conjunctive coefficients of impact are used, which are calculated as a result of the sensitivity analysis of the Web service generalized quality criterion to changes the partial quality criteria. This method underlies the proposed approach to comparing the efficiency of the LSP method with other MCDM methods, which consists of using the obtained weights as the weights of the input criteria for the MCDM methods.

Results. The developed method and approach was verified experimentally. The Web service ranking produced by the LSP method was compared with the ones produced by SAW, AHP, TOPSIS and VIKOR methods. This comparison confirmed the efficiency of the proposed method and approach.

Conclusions. From the obtained results of comparing the LSP method and the MCDM methods considered in this study, it follows that the proposed method and approach provide the equivalent input conditions for these methods as for the LSP method, which is a necessary condition for the correct comparison of MCDM methods. The use of the proposed approach made it possible to study the sensitivities of the considered MCDM methods. In practical applications, this approach can be used to select a suitable MCDM method. The proposed method can be useful for creating professional evaluation systems in which it is necessary to assess the importance (weights) of tens and hundreds of quality criteria.

KEYWORDS: quality of Web service, Logical Scoring of Preference method, ranking measure, SAW, AHP, TOPSIS, VIKOR.

\section{ABBREVIATIONS}

AHP is an Analytic Hierarchy Process;

CPA/DPA is a Conjunction/Disjunction Partial Absorption;

DCG is a Discounted Cumulative Gain;

ELECTRE is an ELimination Et Choice Translating REality;

GCD is a Generalized Conjunction/Disjunction;

GL is a Graded Logic;

HPC/SPC is a Hard/Soft Partial Conjunction;

HPD/SPD is a Hard/Soft Partial Disjunction;

IDCG is an Ideal Discounted Cumulative Gain;

LSP is a Logical Scoring of Preference;

MCDM is a multi-criteria decision-making;

nDCG is a Normalized Discounted Cumulative Gain;

OWA is an Ordered Weighted Averaging;

QoS is a quality of service;

QUALIFLEX is a QUALItative FLEXible;

RCI is a Rank Consistency Index;
SAW is a Simple Additive Weighting;

TOPSIS is a Technique for Order of Preference by Similarity to Ideal Solution;

VIKOR is a VIse Kriterijumska Optimizacija Kompromisno Resenje;

WPM is a weighted power mean;

WsRF is a Web services Relevance Function.

\section{NOMENCLATURE}

$E_{0}$ is a global QoS criterion (preference) of the Web service;

$E_{j}$ is a $j$-th local QoS criterion of the Web service;

$R C I_{k}$ is a Rank Consistency Index of $k$-th MCDM method;

$r$ is a power in WPM function;

$S_{i}$ is an identifier of the $i$-th Web service alternative;

$W_{1}, W_{2}$ are the weights of CPA function; 
$w_{j}$ is the weight of $j$-th local QoS criterion;

$\alpha$ is a degree of the andness parameter;

$\gamma_{j}$ is a conjunctive coefficient of impact of the $j$-th QoS local criterion.

\section{INTRODUCTION}

Every day people are faced with the problem of choosing or selecting a subject and behavioural entities among their possible alternatives. This also applies to the choice of web services as they have become a part of people's daily life. For example, payment services, professional and personal E-shopping and E-commerce services, postal services, buying transport tickets services, booking a hotel services, etc. The problem of selecting Web services arises when creating and orchestrating composite services that involve several separate (atomic) services. This problem in many cases is due to the fact that there are a large number of services with the equal or similar functions, but the consumer may have different requirements for the quality characteristics of services, for instance, cost, response time, throughput, security, availability, etc. Such Web service characteristics are named non-functional characteristics or QoS. Therefore, the problem of choice is to select services suitable for the consumer QoS. This problem usually is formulated as MCDM [1].

The object of study is a process of QoS-based ranking Web services using MCDM methods.

There are many approaches to the selection of QoSbased Web services selecting with MCDM methods. However, these methods can produce different and even inconsistent ranking results. Therefore, it is recommended to compare and select the most appropriate methods depending on the context of the selection process. For the appropriate comparison of ranking methods, it is necessary to provide similar conditions and initial data and this process is also no simple task.

The subject of study is the LSP method, which allows more thoroughly than other MCDM methods to select the Web service on the base QoS properties and user's preferences.

The purpose of the work is to develop an approach that allows to correctly compare the results of Web service ranking by the LSP method with the ranking results of produced other MCDM methods.

Many popular MCDM methods are applied to the QoS-driven Web service selection, for example SAW, AHP, TOPSIS, VIKOR, ELECTRE, etc. A description of these and many other MCDM methods can be found, for example, in [2-4]. The LSP method [5] is different from these methods. The main differences are as follows: first, LSP takes into account user preferences more strictly through the use of such characteristics as simultaneity and substitutability of criteria; secondly, the use of composite aggregating functions makes it possible to more carefully aggregate small groups of criteria; third, the method allows adjusting the relationship between mandatory, sufficient and desirable criteria. The use of these criteria characteristics by the LSP method, together with such human (C) Polska O. V., Kudermetov R. K., Shkarupylo V. V., 2021 DOI 10.15588/1607-3274-2021-2-14 perception characteristics of importance and preference, make it possible to more accurately evaluate the quality of the selectable object and, respectively, to make a decision close to optimal.

\section{PROBLEM STATEMENT}

The LSP method is based on GL, which is an extension of traditional logic $[5,6]$. Although GL can be implemented with different functions, the WPM is more often used:

$$
\begin{gathered}
E_{0}=\left(w_{1} E_{1}^{r}+\ldots+w_{n} E_{n}^{r}\right)^{1 / r}, \\
0 \leq w_{j} \leq 1, \quad \sum_{j=1}^{m} w_{j}=1 .
\end{gathered}
$$

In this function, the parameter $r$ is used to express logical relationships between criteria. The main logical relationships between the criteria are set by the andness or orness parameter. The andness degrees of gradations are presented in Table 1. The building of the criteria hierarchy is used in the LSP. This hierarchy is designed to form groups, subgroups and individual criteria, which are then, aggregated using GL functions with different andness values. The andness values are chosen depending on what requirements are imposed on quality characteristics: mandatory, sufficiency, desirability, as well as simultaneity and substitutability.

The MCDM methods can produce different results $[7,8]$. It depends both on the aggregation function used in the method, and on the normalization techniques, which are needed in almost all MCDM methods. The LSP method uses mainly WPM functions to aggregate criteria. In addition, some criteria can be aggregated using the partial absorption functions CPA and DPA. For these functions, the weights of the input criteria are determined using penalties and rewards that the user allows for decreasing or increasing the values of some criteria relative to other criteria. Therefore, when building a composite LSP aggregator, a complete list of criteria weights may be missing.

To select the MCDM method for solving a specific problem, it is important (recommended) [9] to compare several methods with each other. Thus, the problem arises of how to compare the effectiveness of the LSP method with the effectiveness of other MCDM methods and how to compare the provided by these methods ranking results of the alternatives.

\section{REVIEW OF THE LITERATURE}

There are known many studies on the application of MCDM methods for QoS based Web service selection, e.g. AHP [1], SAW [10], WsRF [11], ELECTRE [12], TOPSIS $[13,14]$. In these studies, QoS preference is mainly determined by assessing the importance of each quality characteristic. This importance is usually represented as a normalized numeric value called weight. A detailed survey of the Web service selection and MCDM methods can be found in [15]. The application of the LSP 
method for QoS-based Web services ranking investigated in [16-18].

In papers $[17,18]$, the LSP method applied for automated QoS-based dynamic evaluation and selection of Web services. For this, the OWA method proposed by R. Yager (see, e.g., [19]) was used to determine the weights of the quality characteristics that are not mandatory. The disadvantage of this approach is that only one aggregator is used that implements the CPA function. This bounds the capabilities of the LSP method because OWA does not support the models of simultaneity and substitutability that are the significant feature of the LSP method.

For conclusively decision making with the MCDM method, it is recommended to compare the results obtained by this method with the results produced by other MCDM methods. The main described in the literature methods for comparison of the MCDM methods can be divided into methods comparison ranking sensitivities and methods comparison consistency rankings by ranking measures $[20,21]$. The sensitivity analysis allows verifying the MCDM method in terms of the correct method parameters selection. The work [8] described an approach for comparing the SAW and TOPSIS methods based on the sensitivity of the ranking to the initial data and the weights of the criteria.

In paper [7], the results of comparison of decisions obtained by the TOPSIS, COPRAS, VIKOR and ELECTRE methods presented. For this, an analysis of the sensitivity of ratings to changes in criteria weight and methods consistency to varying measurement scales and criteria formulations used. In this work, one of the criteria for choosing the most suitable MCDM method is the stability of the produced by method rating to changes in the weight of the criteria. This approach is applicable if the ranges of the weights are known. In addition, taking into account that weights are normalized, the change of one weight of the input criteria requires the change of one or several other weights. This makes it difficult to analyze the true effect of each weight on the stability of the MCDM method. The authors of [22] proposed a method for finding new criterion weights when one of them is changed and used it to study the sensitivity of the QUALIFLEX and VIKOR methods on the weight variations.

In paper [8] the method and algorithm for statistically sensitivity analysis of the TOPSIS method were proposed. As the research result, the conclusion that the TOPSIS method is sensitive to input criteria distribution and the complying of the distributions of the TOPSIS criterion values of alternatives with the input criteria distributions was made. A significant computationally intensive may be required for the practical application of this method. Nevertheless, the applied approach can be useful for researching other MCDM methods, especially for methods in which it is difficult to clearly represent the causal relationship between the input values of the criteria and the result of alternatives ranking.

The authors of [23] used the sensitivity analysis of the VIKOR method to determine the stability solutions to the (C) Polska O. V., Kudermetov R. K., Shkarupylo V. V., 2021 DOI 10.15588/1607-3274-2021-2-14 criteria weights change. The sets of weights were determined by repeating the process of applying the AHP method and matrix of pairwise comparisons. The main drawback of this approach is that can impact to decision maker preference.

The integrated AHP-TOPSIS approach was proposed in [24]. In this approach, the AHP method was applied to determine the criteria weights and TOPSIS was adopted to select the optimal alternatives. Sensitivity analysis was performed by adjusting the weights obtained from the AHP procedures. The disadvantage of this sensitivity analysis is that it only aims to raise awareness among project participants of the potential impact on solutions by decision makers.

Summing up the works reviewed, it can be stated that the investigation of sensitivity analysis of MCDM methods is actual. The results of MCDM methods depend not only on the characteristics of the alternatives but also on the MCDM method used [7]. In addition, there is no consensus on how to determine the "quality" of the MCDM method and the reliability of its result [23].

\section{MATERIALS AND METHODS}

In this paper, a method to compare the results of the LSP method with other methods for QoS-based ranking Web services was proposed. The main idea of this method is to use the sensitivity of the LSP aggregation schema to variations of Web service quality characteristics to calculate the importance or weights of the input attributes for traditional MCDM methods. Attribute weights are calculated by normalizing sensitivity values. To test this idea, these weights were used as the input attribute weights in SAW, AHP, TOPSIS and VIKOR methods. The obtained ranking results were compared with the result of the LSP method ranking using the $\mathrm{nDCG}$ and RCI measures.

To build the aggregating schema of the LSP method, a tree of the Web services quality attributes was built. The Web services quality attributes tree is shown in Fig. 1. Formation of the criteria tree was carried out taking into account the existing Web service QoS factors standard [25], the dataset of the real Web services [26] and described in detail in [27].

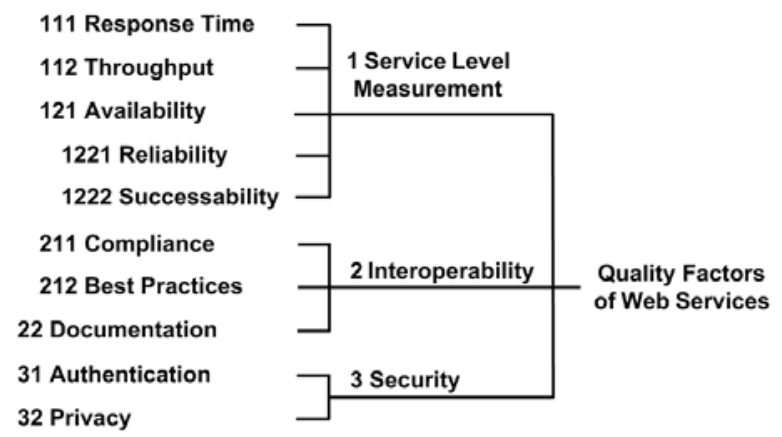

Figure 1 - The tree of the Web services quality attributes

The synthesis of the LSP aggregation schema was made taking into account the preferences of the "ordinary" user of the Web service. For this, the GCD func- 
tions realized as WPM were used. The main parameters of GCD functions shown in Table 1. The WPM functions parameter $r$ depends on the andness parameter $\alpha$. The andness degree for each function was determined based on such requirements for quality attributes as mandatory, optional, sufficiency, simultaneity and substitutability. The mandatory type means that the requirement on quality characteristic is very important and must be satisfied. The optional type means that the satisfaction of the requirement on quality characteristic is desired, but not necessary. The importance of each quality attribute is assigned using weight.

Table 1 - GCD functions

\begin{tabular}{|c|c|c|c|c|c|}
\hline GCD & Sym & $\alpha$ & $r$ & $r,(n=2)$ & type \\
\hline $\mathrm{D}$ & $\mathrm{D}$ & 0 & $r=+\infty$ & $+\infty$ & \multirow{5}{*}{ 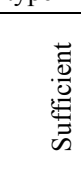 } \\
\hline \multirow{6}{*}{ HPD } & $\mathrm{D}++$ & $1 / 16$ & \multirow{6}{*}{$2 \leq r<+\infty$} & 20.36 & \\
\hline & $\mathrm{D}+$ & $1 / 8$ & & 9.521 & \\
\hline & $\overline{D+-}$ & $3 / 16$ & & 5.802 & \\
\hline & DA & $1 / 4$ & & 3.929 & \\
\hline & $\mathrm{D}-+$ & $5 / 16$ & & 2.792 & \multirow{7}{*}{ 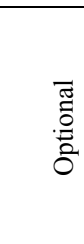 } \\
\hline & D- & $3 / 8$ & & 2.018 & \\
\hline SPD & $\mathrm{D}-$ & $7 / 16$ & $1<r<2$ & 1.449 & \\
\hline A & A & $1 / 2$ & $r=1$ & 1 & \\
\hline \multirow{2}{*}{ SPC } & $\mathrm{C}-$ & $9 / 16$ & \multirow{2}{*}{$0<r<1$} & 0.619 & \\
\hline & $\mathrm{C}-$ & $5 / 8$ & & 0.261 & \\
\hline \multirow{5}{*}{ HPC } & $\mathrm{C}-+$ & $11 / 16$ & \multirow{5}{*}{$-\infty<r \leq 0$} & -0.148 & \\
\hline & $\mathrm{CA}$ & $3 / 4$ & & -0.72 & \multirow{5}{*}{ 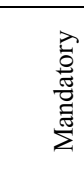 } \\
\hline & $\mathrm{C}+-$ & $13 / 16$ & & -1.655 & \\
\hline & $\mathrm{C}+$ & $7 / 8$ & & -3.51 & \\
\hline & $\mathrm{C}++$ & $15 / 16$ & & -9.06 & \\
\hline $\mathrm{C}$ & $\mathrm{C}$ & 1 & $r=-\infty$ & $-\infty$ & \\
\hline
\end{tabular}

In addition to the GCD functions, the LSP method uses the partial absorption aggregators CPA and DPA. These aggregators are designed to aggregate criteria that are of different types (mandatory, optional and sufficient). For instance, the CPA function aggregates mandatory criterion with optional criterion. This CPA function is shown in Fig. 2 [28].

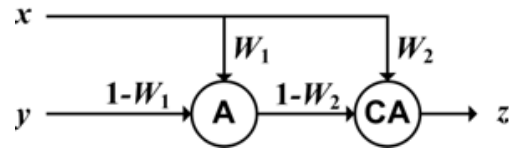

Figure 2 - An example of the CPA function

The input $x$ of the CPA function in Fig. 2 is mandatory, and the input $y$ is optional. The weights $W_{1}$ and $W_{2}$ are determined on the so-called penalty and reward, which are assigned by the user who selects the Web service.

The penalty is the degree to which the user agrees to reduce the aggregate satisfaction rate when a mandatory input is partially satisfied and an optional input is not satisfied. A reward is the degree to which a user wishes to increase the aggregate degree of satisfaction if a mandatory input is partially satisfied and an optional input is fully satisfied. The dependencies of the weights $W_{1}$ and $W_{2}$ on penalties and rewards for the partial absorption functions are given in special tables developed by J. Dujmović in [29]. The output value of this CPA aggregator is determined by the formula (2):

$$
z=\left\{\left(1-W_{2}\right)\left[W_{1} x+\left(1-W_{1}\right) y\right]^{r}+W_{2} x^{r}\right\}^{1 / r},
$$

where $r=-0.72$.

As a result of the combination of WPM and CPA functions and taking into account the criteria tree, the LSP schema for the global aggregation of Web services quality criteria was synthesized. The detailed procedure of LSP aggregation schema synthesis explained in [30]. This aggregation schema is shown in Fig. 3.

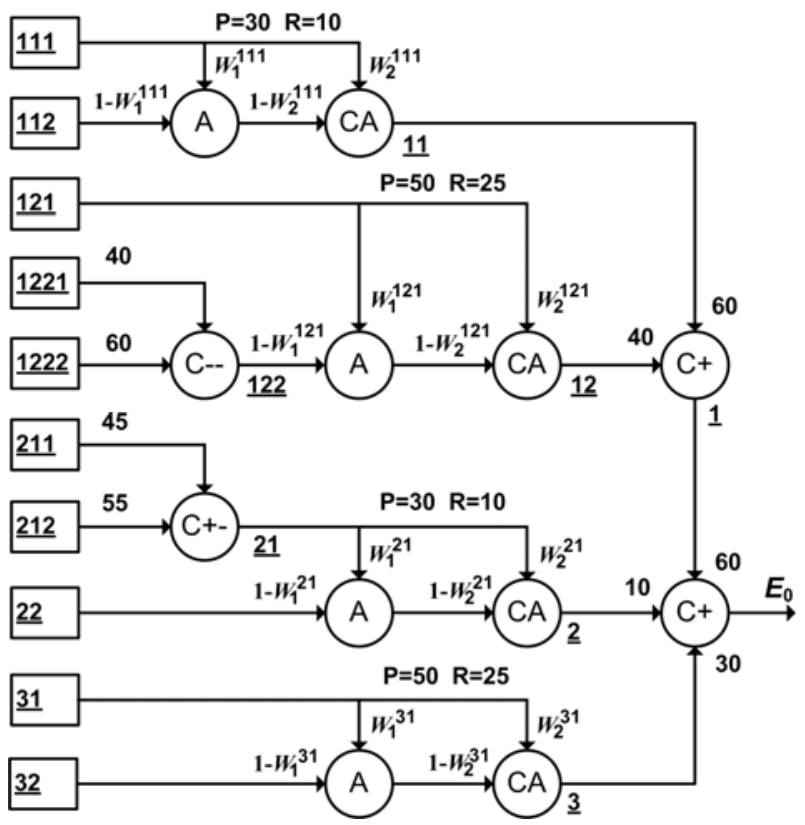

Figure 3 - Aggregate schema

The sensitivity was defined by keeping fixed all input attributes except one and then investigating the effects of the selected input on the aggregation schema output.

Obviously, the quality of service will improve as any of the quality attributes improve. For example, as the response time decreases, overall satisfaction with the Web service will increase. The response time attribute can be critical for the "ordinary" user of the Web service. This means that if the response time is longer than a certain value, then the Web service may be rejected by the user. In this case, the user's satisfaction with the quality of Web service monotonously changes from complete dissatisfaction to complete satisfaction. On the other hand, an attribute such as throughput of the Web service may not be a critical factor (rather, this factor is critical for the Web service provider). In this case, increasing the throughput improves the overall quality of Web service, but the user can agree to some fixed minimum value for this attribute. These cases of changes of the output suitability to variation in critical (mandatory) and optional attributes (input suitability) are shown in Fig. 4. The sen- 
sitivity curves in Fig. 4 are increasing concave functions for which the first derivative with respect to the variable $x_{j}$ of the input attribute $\partial E_{0} / \partial x_{j}>0$, and the second derivative $\partial^{2} E_{0} / \partial x_{j}^{2}<0$.

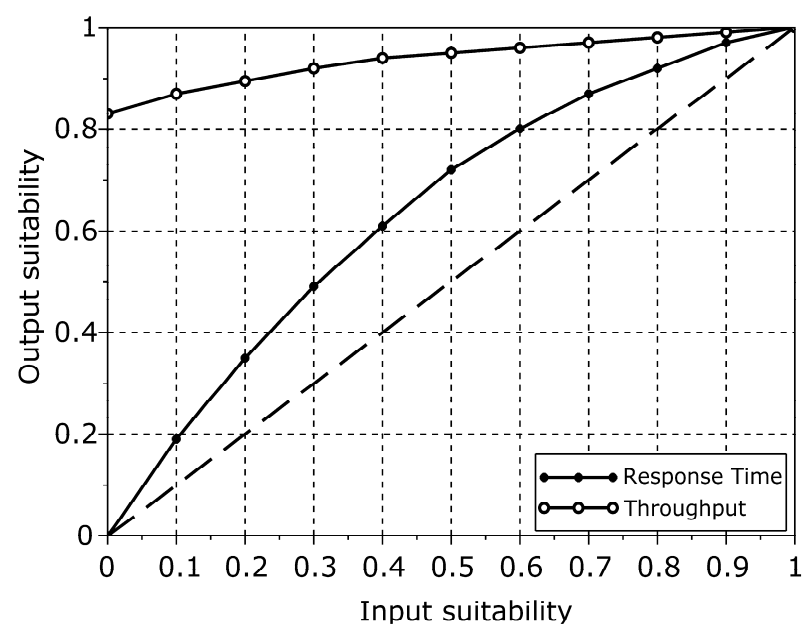

Figure 4 - The shapes of conjunctive sensitivity curves for mandatory and optional criteria

If all input attributes are fixed except one and are maximum, then the maximum impact of the unfixed attribute on the output is when $E_{0}=x_{j}$. For this case in

Fig. 4 corresponds to the dotted line. Sensitivity can be interpreted as the ratio of the area above the sensitivity curve to the area above the straight line of maximum impact. To assess the sensitivity of the output of the LSP aggregator to the input attribute variation, J. Dujmović introduced the conjunctive coefficient of impact [5], which takes into account the shape of the sensitivity curve:

$$
\gamma_{j}=200 \frac{y_{j}^{(\max )}-\int_{0}^{1} f_{j}\left(x_{j}\right) d x_{j}}{y_{j}^{(\max )}},[\%],
$$

where $y_{j}^{(\max )}$ is the maximum value of the output suitability (maximum value of the output of the aggregator), $f_{j}\left(x_{j}\right)$ is the function of the sensitivity of the output suitability to a change in $j$-th input suitability (the value of the input attribute $x_{j}$ ).

The effect of each input attribute on the output of the aggregation schema in Fig. 3 is obtained experimentally, and then conjunctive coefficients of impact are calculated by formula (3). The input attribute weights are calculated using the formula (4):

$$
w_{j}=\gamma_{j} / \sum_{j} \gamma_{j}
$$

(C) Polska O. V., Kudermetov R. K., Shkarupylo V. V., 2021 DOI 10.15588/1607-3274-2021-2-14
These weights of input attributes can be used for SAW, AHP, TOPSIS, VIKOR methods in order to compare the ranking results of these methods with the results of ranking by the LSP method.

To evaluate the consistency of the ranking results by the LSP method and listed above methods, the nDCG and the RCI rank measures were used. The nDCG rank measure evaluate the degree of coincidence of the ranking results according to the positions of Web service alternatives in the ratings [31]. For computing the values of the nDCG of each MCDM methods, the following formulae were used [32]:

$$
\begin{gathered}
D C G=\sum_{i=1}^{n} \frac{\operatorname{rel}\left(S_{i}\right)}{\log _{2}(i+1)}, \\
n D C G=\frac{D C G}{I D C G},
\end{gathered}
$$

where $n$ is a number of Web service alternatives, $\operatorname{rel}\left(S_{i}\right)$ is a relevance of Web service alternative at the $i$ th position and the IDCG is the DCG of the rating produced by LSP method.

The RCI rank measure was used to evaluate the consistency of the ranking result of each MCDM methods with the ranking results of all considered MCDM methods. The RCI rank measure was introduced in [20], applied in [21] and modified in [33,34]. The formula for calculating the RCI is as follows (7):

$$
R C I_{k}=\frac{1}{(K-1)} \sum_{l=1}^{K-1} l \cdot t_{k, l},
$$

where $K$ is a number of compared MCDM methods, $t_{k, l}$ is a total number of times when $k$-th MCDM method produced the same ranking as $l$ other MCDM methods.

\section{EXPERIMENTS}

Based on the dataset [26] a list of 52 currently running Web services with similar functionality was compiled for a numerical experiment. Missing data, but needed according to the attribute tree presented in Fig. 1, was generated randomly. The method proposed in [1] was used to generate the values of the Authentication attribute. This method evaluates the quality characteristics presented as an ordered list. To calculate the values of the Authentication attribute, an ascending ordered list (Password, Certificate Based Authentication, One Time Password, Access Key Authentication, and Token Based Authentication) was used. Further, Web services with dominated quality characteristics vectors were excluded from the list of candidate Web services. As a result, a list of $7 \mathrm{Web}$ service candidates $\left(\mathrm{S}_{1}-\mathrm{S}_{7}\right)$ for selection was formed. The values of these quality characteristics are presented in Table 2. The additional data of quality attributes, shown in Table 3 , include the value ranges of the input attributes, their types and tendencies, which were used to build the LSP 
aggregation schema. The elementary quality criteria of the Web services were calculated according to formulae (8) and (9) and taking to account the values, bands and tendencies of input quality attributes. The values of these criteria is shown in Table 4. Formula (8) is used to calculate criteria with a "benefit" tendency, which means that the higher value of the quality attribute is better than the lower one (for example throughput). Formula (9) is used to calculate criteria with a "cost" tendency, which means that the lower value of the quality attribute is better than the higher one (for example, response time).

Table 2 - Quality attributes for Web services

\begin{tabular}{|l|l|l|l|l|l|l|l|}
\hline \multirow{2}{*}{\multicolumn{1}{c|}{ Criteria }} & \multicolumn{7}{|c|}{ Alternatives ID } \\
\cline { 2 - 8 } & $\mathrm{S}_{1}$ & $\mathrm{~S}_{2}$ & $\mathrm{~S}_{3}$ & $\mathrm{~S}_{4}$ & $\mathrm{~S}_{5}$ & $\mathrm{~S}_{6}$ & $\mathrm{~S}_{7}$ \\
\hline Response Time & 114 & 113 & 108 & 132 & 120 & 100 & 140 \\
\hline Throughput & 16.0 & 10.0 & 12.0 & 20.0 & 17.0 & 21.0 & 23.0 \\
\hline Availability & 86 & 91 & 89 & 83 & 98 & 88 & 75 \\
\hline Reliability & 73 & 70 & 74 & 68 & 83 & 59 & 88 \\
\hline Successability & 86 & 85 & 90 & 77 & 96 & 90 & 98 \\
\hline Compliance & 89 & 78 & 92 & 81 & 85 & 88 & 80 \\
\hline Best Practices & 84 & 83 & 93 & 80 & 90 & 66 & 86 \\
\hline Documentations & 60 & 62 & 90 & 89 & 72 & 52 & 95 \\
\hline Authentication & 17 & 12 & 13 & 14 & 11 & 19 & 15 \\
\hline Privacy & 1 & 0 & 1 & 1 & 0 & 1 & 0 \\
\hline
\end{tabular}

Table 3 - Additional data for Quality attributes

\begin{tabular}{|l|l|l|l|l|}
\hline QoS & \multicolumn{1}{|c|}{$\min$} & $\max$ & \multicolumn{1}{c|}{ type } & tendency \\
\hline Response Time, $\mathrm{ms}$ & 50 & 150 & mandatory & cost \\
\hline Throughput, invokes/s & 5 & 25 & optional & benefit \\
\hline Availability, \% & 60 & 100 & mandatory & benefit \\
\hline Reliability, \% & 40 & 100 & optional & benefit \\
\hline Successability, \% & 20 & 100 & optional & benefit \\
\hline Compliance, \% & 30 & 100 & mandatory & benefit \\
\hline Best Practices, \% & 40 & 100 & mandatory & benefit \\
\hline Documentations, \% & 20 & 100 & optional & benefit \\
\hline Authentication & 2 & 20 & mandatory & benefit \\
\hline Privacy & 0 & 1 & optional & benefit \\
\hline
\end{tabular}

$$
\begin{aligned}
& E_{i}\left(x_{j}\right)=\max \left[0, \min \left(1, \frac{x_{i j}-x_{j}^{(\min )}}{x_{j}^{(\max )}-x_{j}^{(\min )}}\right)\right], \\
& E_{i}\left(x_{j}\right)=\max \left[1, \max \left(0, \frac{x_{j}^{(\max )}-x_{i j}}{x_{j}^{(\max )}-x_{j}^{(\min )}}\right)\right] .
\end{aligned}
$$

Table 4- QoS criteria

\begin{tabular}{|l|c|c|c|c|c|c|c|}
\hline \multirow{2}{*}{\multicolumn{1}{c|}{ Criteria }} & \multicolumn{7}{|c|}{ Alternatives ID } \\
\cline { 2 - 8 } & $\mathrm{S}_{1}$ & $\mathrm{~S}_{2}$ & $\mathrm{~S}_{3}$ & $\mathrm{~S}_{4}$ & $\mathrm{~S}_{5}$ & $\mathrm{~S}_{6}$ & $\mathrm{~S}_{7}$ \\
\hline Response Time & 0.36 & 0.37 & 0.42 & 0.18 & 0.30 & 0.50 & 0.10 \\
\hline Throughput & 0.55 & 0.25 & 0.35 & 0.75 & 0.60 & 0.80 & 0.90 \\
\hline Availability & 0.65 & 0.77 & 0.72 & 0.57 & 0.95 & 0.70 & 0.37 \\
\hline Reliability & 0.55 & 0.50 & 0.57 & 0.47 & 0.72 & 0.32 & 0.80 \\
\hline Successability & 0.82 & 0.81 & 0.87 & 0.71 & 0.95 & 0.87 & 0.97 \\
\hline Compliance & 0.84 & 0.69 & 0.89 & 0.73 & 0.78 & 0.83 & 0.71 \\
\hline Best Practices & 0.73 & 0.72 & 0.88 & 0.67 & 0.83 & 0.43 & 0.77 \\
\hline Documentations & 0.50 & 0.52 & 0.87 & 0.86 & 0.65 & 0.40 & 0.94 \\
\hline Authentication & 0.83 & 0.56 & 0.61 & 0.67 & 0.50 & 0.94 & 0.72 \\
\hline Privacy & 1 & 0 & 1 & 1 & 0 & 1 & 0 \\
\hline
\end{tabular}

The QoS criteria presented in Table 4 were used as inputs for the LSP aggregation schema (Fig. 3). The Web services $\mathrm{S}_{1}-\mathrm{S}_{7}$ ranks and LSP aggregation schema sensitivities on changes of each criterion were obtained. Sensitivity curves are shown in Fig. 5 and Fig. 6. Then the sensitivity characteristics were used for calculating the weights criteria according to formula (4). These criteria weights are $[0.236,0.04,0.162,0.02,0.034,0.116,0.128$, $0.013,0.174,0.078]$.

In order to verify the proposed method, the values of considered list of input quality attributes (Table 2) was used to rank Web services by methods SAW, AHP, TOPSIS and VIKOR. For this the weights obtained as a result of calculating the sensitivity of the LSP aggregation schema were used.

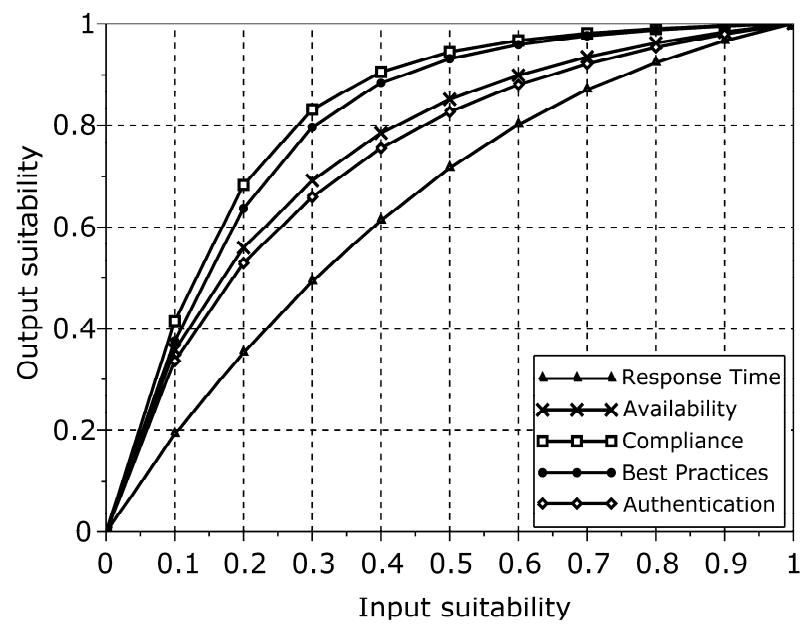

Figure 5 - Sensitivity curves for mandatory criteria

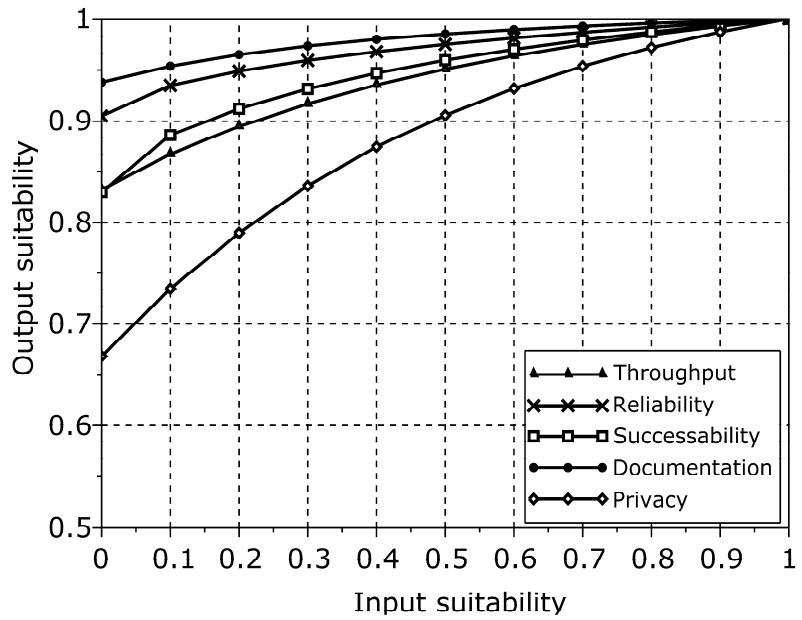

Figure 6 - Sensitivity curves for optional criteria

The sensitivity analysis of the SAW, AHP, TOPSIS and VIKOR methods was carried out similarly to the sensitivity analysis of the LSP method.

\section{RESULTS}

Table 5 shows the sensitivities of the considered MCDM methods to changes in each of the input attributes, as well as the average values of the sensitivity of each method. The sensitivity was calculated in accordance 
with formula (3). As a function $f_{i}\left(x_{i}\right)$, the functions of the methods sensitivity curves was used. The maximum value of output suitability is obviously $y_{i}$ equal to 1 (see Fig. 4).

Table 5 - Sensitivities of MCDM methods $\left(\gamma_{i}, \%\right)$

\begin{tabular}{|c|c|c|c|c|c|}
\hline & ڤิ & 否 & 昰 & $\begin{array}{l}\mathscr{n} \\
\tilde{D} \\
\stackrel{0}{0}\end{array}$ & $\begin{array}{l}\stackrel{\sim}{0} \\
\stackrel{y}{J} \\
>\end{array}$ \\
\hline Response Time & 71.04 & 23.61 & 6.62 & 36.07 & 23.61 \\
\hline Throughput & 12.010 & 3.99 & 2.04 & 14.92 & 3.99 \\
\hline Availability & 48.61 & 16.16 & 3.32 & 20.74 & 16.16 \\
\hline Reliability & 6.01 & 2.00 & 0.58 & 4.21 & 2.00 \\
\hline Successability & 10.18 & 3.38 & 0.63 & 4.27 & 3.83 \\
\hline Compliance & 34.88 & 11.59 & 1.53 & 9.97 & 11.59 \\
\hline Best Practices & 38.38 & 12.76 & 3.26 & 20.33 & 12.76 \\
\hline Documentations & 3.93 & 1.31 & 0.53 & 3.92 & 1.31 \\
\hline Authentication & 52.33 & 17.39 & 7.40 & 49.37 & 17.39 \\
\hline Privacy & 23.52 & 7.082 & 7.41 & 49.90 & 7.082 \\
\hline Average & 30.09 & 10.00 & 3.33 & 21.37 & 10.00 \\
\hline
\end{tabular}

Table 6 presents the results of Web service rankings obtained by MCDM methods and comparing these rankings using the rank measures nDCG and RCI. As mentioned above, the LSP ranking was chosen as the ideal ranking for the $\mathrm{nDCG}$ measure, since other methods use weights derived from the LSP method. The obtained high values of $\mathrm{nDCG}$ indicate that the SAW, AHP, TOPSIS and VIKOR methods determined the ranks of Web services in sufficient consistently with the LSP method. The RCI indicators received average values (the maximum indicator for these data is 7). This is since the considered methods differ in ranking and normalization of the input attributes techniques. These techniques can sufficiently affect alternatives with the low overall quality criterion. Nevertheless, the ranking results are quite consistent for the Web services which took place in the first three positions in the rankings.

Table 6 - Ranks of Web services and evaluations of $\mathrm{nDCG}$ and RCI measures

\begin{tabular}{|c|c|c|c|c|c|}
\hline Service ID & 穴 & 岕 & 昰 & 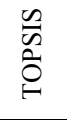 & $\begin{array}{l}\stackrel{\alpha}{0} \\
\stackrel{y}{J}\end{array}$ \\
\hline $\mathrm{S}_{1}$ & 3 & 2 & 2 & 2 & 3 \\
\hline $\mathrm{S}_{2}$ & 6 & 7 & 7 & 7 & 6 \\
\hline $\mathrm{S}_{3}$ & 2 & 3 & 3 & 3 & 2 \\
\hline $\mathrm{S}_{4}$ & 5 & 4 & 4 & 4 & 5 \\
\hline $\mathrm{S}_{5}$ & 4 & 5 & 5 & 6 & 4 \\
\hline $\mathrm{S}_{6}$ & 1 & 1 & 1 & 1 & 1 \\
\hline $\mathrm{S}_{7}$ & 7 & 6 & 6 & 5 & 7 \\
\hline$n D C G,[\%]$ & 100 & 98 & 98 & 98.4 & 99.7 \\
\hline$R C I$ & 2.5 & 3.5 & 3.5 & 3.0 & 2.5 \\
\hline
\end{tabular}

\section{DISCUSSION}

The comparison of the results of ranking by the LSP method and the SAW, AHP, TOPSIS and VIKOR methods confirmed the possibility of using the weights obtained from the LSP sensitivity analysis as the input attributes weights for the SAW, AHP, TOPSIS and VIKOR (C) Polska O. V., Kudermetov R. K., Shkarupylo V. V., 2021 DOI 10.15588/1607-3274-2021-2-14 methods. This indicates the efficiency of the proposed method. At the same time, according to the average values of the method sensitivities to the input criteria changes given in Table 5, it can be concluded that the LSP method has a higher overall sensitivity and especially to changes of mandatory criteria.

The develop a hierarchical tree of a set of input attributes for the LSP method facilitates to build the separate aggregators for small groups of input attributes (usually 2 to 5) with flexible consideration of such requirements for quality attributes as mandatory, sufficiency, optional, simultaneity and substitutability. These requirements are further taken into account when synthesizing the general aggregation schema. This approach makes it possible to more thoroughly take into account the user's preferences when QoS-based selecting the Web services. As a result, the mapping of the sensitivity of the general LSP aggregation schema to the input weights for other decisionmaking methods turns out to be more accurate and the decisions obtained by them are more relevant to the preferences of decision-makers.

As follows from the publications analyzed in this work, the problem of choosing the MCDM method is of current interest and it is recommended when choosing one to compare the results produced by several MCDM methods. Approaches to compare MCDM methods are constantly evolving. The proposed method can supplement already developed approaches for MCDM methods.

In many cases, for the considered MCDM methods, the main method for determining the input attributes weights is the AHP. Sometimes this method is used repeatedly to clarify the preferences of stakeholders or decision makers. The process of identifying user preferences is most advanced in the LSP method. Therefore, the proposed method, based on the determination of weights from the results of sensitivity analysis, can also be used to check or confirm the weights obtained by the AHP or other methods. This can be especially useful if the number of input attributes is a large.

\section{CONCLUSIONS}

In this work, the approach to comparing the effectiveness of the LSP method with other MCDM methods has been proposed.

The scientific novelty of this study is as follows:

- a method based on the LSP sensitivity analysis for calculating input criteria weights has been developed. These weights can be applied to other MCDM methods when compared to the LSP method;

- a comparison of the sensitivity of the LSP method with the sensitivity of SAW, AHP, TOPSIS and VIKOR methods to changes in input attributes have been made;

- to compare the ratings produced by the LSP, SAW, AHP, TOPSIS and VIKOR methods, the nDCG and RCI measures have been used.

The practical significance of the results obtained is that the developed method can be used to calculate the weights of input attributes, and the proposed approach can be used to verify the results of ranking alternatives, which 
may be necessary when choosing the most suitable MCDM method.

Prospects for further research are the use of the proposed approach and method for comparing the LSP method with methods that do not have an explicit aggregation function, for example, ELECTRE and expanding the list of QoS criteria for selecting Web services.

\section{REFERENCES}

1. Tran V. X., Tsuji H., Masuda R. A new QoS ontology and its QoS-based ranking algorithm for Web services, Simulation Modelling Practice and Theory, 2009, Vol. 17, No. 8, pp. 1378-1398. DOI: 10.1016/j.simpat.2009.06.010

2. Tzeng G-H., Huang J-J. Multiple Attribute Decision Making : Methods and Applications. Boca Raton, Chapman and Hall (CRC Press), 2011, 336 p. DOI: 10.1201/b11032

3. Greco S., Ehrgott M., Figueira J. R. eds. Multiple Criteria Decision Analysis : State of the Art Surveys. New York, Springer, 2016, 1346 p. DOI: 10.1007/978-1-4939-3094-4

4. Alinezhad A., Khalili J. New Methods and Applications in Multiple Attribute Decision Making (MADM). Cham, Springer, 2019, 234 p. DOI: 10.1007/978-3-030-15009-9

5. Dujmović J. Soft Computing Evaluation Logic : The LSP Decision Method and Its Applications. Hoboken, John Wiley \& Sons, Inc., 2018, 912 p. DOI: 10.1002/9781119256489

6. Dujmovic J. Graded logic for decision support systems, International Journal of Intelligent Systems, 2019, Vol. 34, № 11, pp. 2900-2919. DOI: 10.1002/int.22177

7. Pamucar D., Bozanic D., Randjelovic A. Multi-criteria decision making : An example of sensitivity analysis, Serbian Journal of Management, 2017, Vol. 12, No. 1, pp. 1-27. DOI: $10.5937 / \mathrm{sjm} 12-9464$

8. Simanavičienè R., Petraityte V. Sensitivity Analysis of the TOPSIS Method in Respect of Initial Data Distributions, Lithuanian Journal of Statistics, 2016, Vol. 55, No. 1, pp. 45-51. DOI: 10.15388/LJS.2016.13866

9. Debnath N., Martellotto P., Daniele M. et al A method to evaluate QoS of web services required by a workflow, ITS Telecommunications : 11th international conference, St. Petersburg, 23-25 August 2011 : proceeding. IEEE, 2011, pp. 640-645. DOI: 10.1109/ITST.2011.6060134

10. Maheswari S., Karpagam G. R. Performance evaluation of semantic based service selection methods, Computers and Electrical Engineering, 2017, Vol. 71, pp. 966-977. DOI: 10.1016/j.compeleceng.2017.10.006

11. Al-Masri E., Mahmoud Q. H. QoS-based Discovery and Ranking of Web Services, Computer Communications and Networks : 16th international conference, Honolulu, 13-16 August 2007 : proceeding. IEEE, 2007, pp. 529-534. DOI: 10.1109/ICCCN.2007.4317873

12. Ma H., Zhu H., Hu Z. et al. Time-aware trustworthiness ranking prediction for cloud services using interval neutrosophic set and ELECTRE, Knowledge-Based Systems 2017, Vol. 138, pp. 27-45. DOI 10.1016/j.knosys.2017.09.027

13. Belouaar H., Kazar O., Rezeg K. Web service selection based on TOPSIS algorithm, Mathematics and Information Technology : International conference, Adrar, 4-5 December 2017 : proceeding. IEEE, 2018, pp. 177-182. DOI: 10.1109/MATHIT.2017.8259713

14. Sun R., Zhang B., Liu T. Ranking web service for high quality by applying improved Entropy-TOPSIS method, Software Engineering, Artificial Intelligence, Networking and
Parallel/Distributed Computing : 17th IEEE/ACIS international conference, Shanghai, 30 May-1 June 2016: proceeding. IEEE, 2016, pp. 249-254. DOI: 10.1109/SNPD.2016.7515909

15. Hosseinzadeh M., Hama H. K., Ghafour M. Y. et al. Service Selection Using Multi-criteria Decision Making : A Comprehensive Overview, Journal of Network and Systems Management, 2020, Vol. 28, № 4, pp. 1639-1693. DOI: 10.1007/s10922-020-09553-w

16. Yu H. Q. and Molina H. A modified Logic Scoring Preference method for dynamic Web services evaluation and selection, Service Oriented Computing : 2nd European Seminar for Young Researchers, Leicester, 11-12 June 2007 : proceedings. Leicester, 2007, pp. 87-93.

17. Yu H. Q., Reiff-Marganiec S. A Method for Automated Web Service Selection, Services - Part I : IEEE congress, Honolulu, 6-11 July 2008 : proceeding. IEEE, 2008, pp. 513-520. DOI: 10.1109/SERVICES-1.2008.8

18. Yu H. Q., Reiff-Marganiec S. Automated Context-Aware Service Selection for Collaborative Systems, Advanced Information Systems Engineering : 21st International Conference, CAiSE 2009, Amsterdam, 8-12 June, 2009 : proceedings. Berlin, Springer, 2009, pp. 261-274. (Lecture Notes in Computer Science, Vol. 5565). DOI: 10.1007/978-3-64202144-2 23

19. Yager R. R. On ordered weighted averaging aggregation operators in multicriteria decisionmaking, IEEE Transactions on Systems, Man, Cybernetics, 1988, Vol. 18, No. 1, pp. 183-190. DOI: 10.1109/21.87068

20. Chakraborty S., Yeh C.-H. A simulation comparison of normalization procedures for TOPSIS, Computers and Industrial Engineering : International conference, Troyes, 6-9 July, 2009 : proceedings. IEEE, 2009, pp. 1815-1820. DOI: 10.1109/iccie.2009.5223811

21. Vafaei N., Ribeiro R. A., Camarinha-Matos L. M. Data normalisation techniques in decision making: case study with TOPSIS method, International Journal of Information and Decision Sciences, 2018, Vol. 10, No. 1, pp. 19-38. DOI: $10.1504 /$ ijids.2018.090667

22. Alinezhad A., Esfandiari N. Sensitivity Analysis in the QUALIFLEX and VIKOR Methods, Journal of Optimization in Industrial Engineering, 2012, Vol. 6, No. 1 (10), pp. 29-34.

23. Muñoz B., Romana M. G., Ordóñez J. Sensitivity Analysis of Multicriteria Decision Making Methodology Developed for Selection of Typologies of Earth-retaining Walls in an Urban Highway, Transportation Research Procedia, 2016, Vol. 18, pp. 135-139. DOI: 10.1016/j.trpro.2016.12.019

24. Tian G., Zhang H., Jia H. et al.Automotive style design assessment and sensitivity analysis using integrated analytic hierarchy process and technique for order preference by similarity to ideal solution, Advances in Mechanical Engineering, 2016, Vol. 8, No. 5, pp. 1-10. DOI: $10.1177 / 1687814016649885$

25. Web Services Quality Factors Version 1.0, Candidate OASIS Standard 01, October 2012 [Electronic resource]. Access mode: http://docs.oasis-open.org/wsqm/WS-QualityFactors/v1.0/cos01/WS-Quality-Factors-v1.0-cos01.html

26. QWS Dataset v2.0, November 2019 [Electronic resource]. Access mode: https://github.com/qwsdata/qwsdata.github.io/releases

27. Polska O. V. Kudermetov R. K., N. V. Shcherbak Model of web services quality criteria hierarchy, Visnik Zaporiz koho natsional noho universitetu. Fiziko-matematichni nauki, 
2020, Vol. 2, pp. 43-51. DOI: 10.26661/2413-6549-2020-206

28. Dujmovic J. J. Continuous Preference Logic for System Evaluation, IEEE Transactions on Fuzzy Systems, 2007, Vol. 15, No. 6, pp. 1082-1099. DOI: 10.1109/TFUZZ.2007.902041

29. Dujmović, J. Partial absorption function, Journal of the University of Belgrade, EE Dept., Series Mathematics and Physics, 1979, No. 659, pp. 156-163.

30. Polska O. V., Kudermetov R. K., Shkarupylo V. V. The approach for QoS based web service selection with user's preferences, Naukovi pratsi Donets koho natsional noho tekhnichnoho universitetu. Problemi modelyuvannya ta avtomatizatsiyi proektuvannya, 2020, No. 16, pp. 19-27. DOI: 10.31474/2074-7888-2020-2-19-27

31. Wang Y., Wang L., Li Y. et al. A Theoretical Analysis of NDCG Ranking Measures, Learning Theory : 26th annual conference, COLT 2013, Princeton, 12-14 June, 2013 : proceedings. JMLR.org, 2013, pp. 25-54.
32. Fogli A., Sansonetti G. Exploiting semantics for contextaware itinerary recommendation, Personal and Ubiquitous Computing, 2019, Vol. 23, pp. 215-231. DOI: 10.1007/s00779-018-01189-7

33. Kudermetov R., Polska O. , Shkarupylo V. et al. Normalization Techniques Comparison for QoS-based Web Services Selection by LSP Method, Intelligent Data Acquisition and Advanced Computing Systems (IDAACS-SWS) : 5th IEEE International Symposium Smart and Wireless Systems within the Conferences, Dortmund, 17-18 September 2020: proceeding. IEEE, 2020, pp. 213-216. DOI: 10.1109/idaacssws50031.2020.9297098

34. Polska O., Kudermetov R., Alsayaydeh J. A. J. et al. QoSaware Web-services Ranking: Normalization Techniques Comparative Analysis for LSP Method, ARPN Journal of Engineering and Applied Sciences, 2021, Vol. 16, No. 2, pp. 248-254.

Received 17.04.2021. Accepted 03.06.2021.

УДК 004.42

\section{ПІДХІД ДО ВИБОРУ ВЕБСЕРВІСІВ ЗА КРИТЕРІЯМИ ЯКОСТІ НА ОСНОВІ АНАЛІЗУ ЧУТЛИВОСТІ МЕТОДІВ МСDМ}

Польська О. В. - старший викладач кафедри комп’ютерних систем та мереж Національного університету «Запорізька політехніка», Запоріжжя, Україна.

Кудерметов Р. К. - канд. техн. наук, доцент, завідувач кафедри комп'ютерних систем та мереж Національного університету «Запорізька політехніка», Запоріжжя, Україна.

Шкарупило В. В. - канд. техн. наук, доцент, доцент кафедри комп'ютерних систем та мереж Національного університету біоресурсів і природокористування України, Київ, Україна

\section{АНОТАЦІЯ}

Актуальність. Розглянуто задачу вибору вебсервісів за критеріями якості зі списку вебсервісів з однаковими або подібними функціональними характеристиками. Це завдання $\epsilon$ невід'ємною частиною процесів пошуку, вибору, узгодження і використання таких вебсервісів в зв'язку з численними пропозиціями вебсервісів в Інтернеті. Розумний вибір необхідного вебсервісу може враховувати безліч вимог користувача до якісних характеристик, наприклад, часу відгуку, пропускної здатності, надійності, вартості тощо. Така задача зазвичай формулюється як багатокритеріальна задача прийняття рішень, в якій параметрами $є$ чинники якості вебсервісів і ступеню значущості параметрів якості. Об'єктом дослідження $є$ процеси ранжування вебсервісів за допомогою методів MCDM з урахуванням переваг та вимог користувача до характеристик якості вебсервісів. Предмет дослідження - метод LSP, який крім ступеню важливості критеріїв, що використовується у всіх методах MCDM, моделює міркування користувача про якість, враховуючи, зокрема, такі характеристики критеріїв, як обов'язковість, достатність, бажаність, одночасність та взаємозамінюванність. Мета дослідження - розробити підхід для порівняння результатів використання методу LSP з іншими методами MCDM.

Метод. Запропоновано метод обчислення ваг вхідних критеріїв, які не завжди задані явно в методі LSP. Для цього використовуються коефіцієнти кон'юнктивного впливу, які обчислюються в результаті процедури аналізу чутливості узагальненого критерію якості до змін вхідних критеріїв якості. Цей метод лежить в основі запропонованого підходу до порівняння ефективності методу LSP з іншими методами MCDM, який полягає в використанні отриманих ваг в якості ваг вхідних критеріїв для МCDM методів.

Результати. Розроблені метод і підхід було перевірено експериментально. В якості MCDM методів, з якими здійснювалось порівняння метод LSP, використовувалися методи SAW, AHP, TOPSIS i VIKOR. Порівняння результатів ранжування вебсервісів цими методами з результатом ранжирування методом LSP підтвердило працездатність запропонованих методу та підходу.

Висновки. 3 отриманих результатів порівняння методу LSP і розглянутих в даному дослідженні методів MCDM випливає, що запропоновані метод і підхід забезпечують для цих методів рівнозначні з методом LSP вхідні умови, що є необхідною умовою коректності порівняння методів MCDM. Використання запропонованого підходу дозволило дослідити чутливості розглянутих методів MCDM. У практичному застосуванні даний підхід можна використовувати для вибору підходящого MCDM методу. Запропонований метод може бути корисний для створення професійних систем оцінювання, коли необхідно оцінювати важливість (ваги) десятків і сотень критеріїв якості.

КЛЮЧОВІ СЛОВА: якість вебсервісу, метод логічного оцінювання вподобань, міри ранжування, SAW, AHP, TOPSIS, VIKOR. 


\section{ПОДХОД К ВЫБОРУ ВЕБ-СЕРВИСОВ ПО КРИТЕРИЯМ КАЧЕСТВА НА ОСНОВЕ АНАЛИЗА ЧУВСТВИТЕЛЬНОСТИ МЕТОДОВ МСDМ}

Польская О. В. - старший преподаватель кафедры компьютерных систем и сетей Национального университета «Запорожская политехника», Запорожье, Украина.

Кудерметов Р. К. - канд. техн. наук, доцент, заведующий кафедрой компьютерных систем и сетей Национального университета «Запорожская политехника», Запорожье, Украина.

Шкарупило В. В. - канд. техн. наук, доцент, доцент кафедры компьютерных систем и сетей Национального университета биоресурсов и природопользования Украины, Киев, Украина.

АННОТАЦИЯ

Актуальность. Рассмотрена задача выбора веб-сервисов по качественным характеристикам из списка веб-сервисов с одинаковыми или подобными функциональными характеристиками. Эта задача является неотъемлемой частью процессов поиска, выбора, согласования и использования таких веб-сервисов в связи с многочисленными предложениями вебсервисов в Интернете. Разумный выбор необходимого веб-сервиса может учитывать множество требований пользователя к качественным характеристикам, например, времени отклика, пропускной способности, надежности, стоимости и т. д. Такая задача обычно формулируется как задача MCDM, в которой параметрами являются факторы качества веб-сервисов и степени значимости параметров качества. Объектом исследования являются процессы ранжирования веб-сервисов с помощью методов MCDM с учетом предпочтений и требований пользователя к характеристикам качества веб-сервисов. Предмет исследования - метод LSP, который помимо степени важности критериев, использующейся во всех методах МCDM, моделирует рассуждения пользователя о качестве, учитывая, в частности, такие характеристики критериев, как обязательность, достаточность, желательность, одновременность и взаимозаменяемость. Цель исследования - разработать подход для сравнения результатов использования метода LSP с другими методами MCDM.

Метод. Предложен метод вычисления весов входных критериев, которые не всегда заданы явно в методе LSP. Для этого используются коэффициенты конъюнктивного влияния, которые вычисляются в результате процедуры анализа чувствительности обобщенного критерия качества к изменениям входных критериев качества. Этот метод лежит в основе предложенного подхода к сравнению эффективности метода LSP с другими методами MCDM, который заключается в использовании полученных весов в качестве весов входных критериев для MCDM методов.

Результаты. Разработанные метод и подход были проверены экспериментально. В качестве MCDM методов, с которыми сравнивался метод LSP, использовались методы SAW, AHP, TOPSIS и VIKOR. Сравнение результатов ранжирования веб-сервисов этими методами с результатом ранжирования методом LSP подтвердило работоспособность предложенных метода и подхода.

Выводы. Из полученных результатов сравнения метода LSP и рассмотренных в данном исследовании методов МСDM следует, что предложенные метод и подход обеспечивают для этих методов равнозначные с LSP входные условия, что является необходимым условием корректности сравнения методов MCDM. Использование предложенного подхода позволило исследовать чувствительности рассмотренных методов MCDM. В практическом применении данный подход можно использовать для выбора подходящего МСDМ метода. Предложенный метод может быть полезен для создания профессиональных систем оценивания, когда необходимо оценивать важность (веса) десятков и сотен критериев качества.

КЛЮЧЕВЫЕ СЛОВА: качество веб-сервиса, метод логического оценивания предпочтений, меры ранжирования, SAW, AHP, TOPSIS, VIKOR.

\section{ЛІТЕРАТУРА / ЛИТЕРАТУРА}

1. Tran V. X. A new QoS ontology and its QoS-based ranking algorithm for Web services / V.X. Tran, H. Tsuji, R. Masuda // Simulation Modelling Practice and Theory 2009. - Vol. 17, № 8. - P. 1378-1398. DOI: 10.1016/j.simpat.2009.06.010

2. Tzeng G-H. Multiple Attribute Decision Making : Methods and Applications / G-H. Tzeng, J-J. Huang. - Boca Raton: Chapman and Hall (CRC Press), 2011. - 336 p. DOI: $10.1201 / \mathrm{b} 11032$

3. Greco S. Multiple Criteria Decision Analysis : State of the Art Surveys / eds.: S. Greco, M. Ehrgott, J. R. Figueira. New York: Springer, 2016. - 1346 p. DOI: 10.1007/978-14939-3094-4

4. Alinezhad A. New Methods and Applications in Multiple Attribute Decision Making (MADM) / A. Alinezhad, J. Khalili - Cham : Springer, 2019. - 234 p. DOI: 10.1007/978-3-030-15009-9

5. Dujmović J. Soft Computing Evaluation Logic : The LSP Decision Method and Its Applications / J. Dujmović. - Hoboken : John Wiley \& Sons, Inc., 2018. - 912 p. DOI: 10.1002/9781119256489

(C) Polska O. V., Kudermetov R. K., Shkarupylo V. V., 2021

DOI 10.15588/1607-3274-2021-2-14
6. Dujmovic J. Graded logic for decision support systems / J. Dujmovic // International Journal of Intelligent Systems 2019. - Vol. 34, № 11. - P. 2900-2919. DOI: 10.1002/int.22177

7. Pamucar D. Multi-criteria decision making : An example of sensitivity analysis / D. Pamucar, D. Bozanic, A. Randjelovic // Serbian Journal of Management. - 2017. Vol.12, № 1. - P. 1-27. DOI: 10.5937/sjm12-9464

8. Simanavičienè R. Sensitivity Analysis of the TOPSIS Method in Respect of Initial Data Distributions / R. Simanavičiene, V. Petraitytė // Lithuanian Journal of Statistics - 2016. - Vol. 55, № 1. - P. 45-51. DOI: 10.15388/LJS.2016.13866

9. A method to evaluate QoS of web services required by a workflow / [N. Debnath, P. Martellotto, M. Daniele et al.] // ITS Telecommunications : 11th international conference, $\mathrm{St}$. Petersburg, 23-25 August 2011 : proceeding. - IEEE, 2011. - P. 640-645. DOI: 10.1109/ITST.2011.6060134

10. Maheswari S. Performance evaluation of semantic based service selection methods / S. Maheswari, G. R. Karpagam // Computers and Electrical Engineering. - 2017. - 
Vol.71. - $\quad$ P $\quad 966-977 . \quad$ DOI: 10.1016/j.compeleceng.2017.10.006

11. Al-Masri E. QoS-based Discovery and Ranking of Web Services / E. Al-Masri, Q. H. Mahmoud // Computer Communications and Networks : 16th international conference, Honolulu, 13-16 August 2007 : proceeding. - IEEE, 2007. P. 529-534. DOI: 10.1109/ICCCN.2007.4317873

12. Time-aware trustworthiness ranking prediction for cloud services using interval neutrosophic set and ELECTRE / [H. Ma, H. Zhu, Z. Hu et al.] // Knowledge-Based Systems 2017. - Vol. 138. - P. 27-45. DOI: 10.1016/j.knosys.2017.09.027

13. Belouaar H. Web service selection based on TOPSIS algorithm / H. Belouaar, O. Kazar, K. Rezeg // Mathematics and Information Technology : International conference, Adrar, 4-5 December 2017 : proceeding. - IEEE, 2018. - P. 177182. DOI: 10.1109/MATHIT.2017.8259713

14. Sun R. Ranking web service for high quality by applying improved Entropy-TOPSIS method / R. Sun, B. Zhang, T. Liu // Software Engineering, Artificial Intelligence, Networking and Parallel/Distributed Computing : 17th IEEE/ACIS international conference, Shanghai, 30 May-1 June 2016: proceeding. - IEEE, 2016. - P. 249-254. DOI: 10.1109/SNPD.2016.7515909

15. Service Selection Using Multi-criteria Decision Making : A Comprehensive Overview / [M. Hosseinzadeh, H. K. Hama, M. Y. Ghafour et al.] // Journal of Network and Systems Management - 2020. - Vol. 28, № 4. - P. 1639-1693. DOI 10.1007/s10922-020-09553-w

16. Yu H. Q. A modified Logic Scoring Preference method for dynamic Web services evaluation and selection / H. Q.Yu, and H. Molina // Service Oriented Computing : 2nd European Seminar for Young Researchers, Leicester, 11-12 June 2007 : proceedings. - Leicester, 2007. - P. 87-93.

17. Yu H. Q. A Method for Automated Web Service Selection / H. Q. Yu, S. Reiff-Marganiec // Services - Part I : IEEE congress, Honolulu, 6-11 July 2008 : proceeding. - IEEE, 2008. - P. 513-520. DOI: 10.1109/SERVICES-1.2008.8

18. Yu H. Q. Automated Context-Aware Service Selection for Collaborative Systems / H. Q. Yu, S. Reiff-Marganiec // Advanced Information Systems Engineering : 21st International Conference, CAiSE 2009, Amsterdam, 8-12 June, 2009 : proceedings. - Berlin : Springer, 2009. - P. 261-274. - (Lecture Notes in Computer Science, Vol. 5565). DOI: 10.1007/978-3-642-02144-2_23

19. Yager R. R. On ordered weighted averaging aggregation operators in multicriteria decisionmaking / R. R. Yager // IEEE Transactions on Systems, Man, Cybernetics. - 1988. Vol. 18, № 1. - P. 183-190. DOI: 10.1109/21.87068

20. Chakraborty S. A simulation comparison of normalization procedures for TOPSIS / S. Chakraborty, C.-H. Yeh // Computers and Industrial Engineering : International conference, Troyes, 6-9 July, 2009 : proceedings. - IEEE, 2009. P. 1815-1820. DOI: $10.1109 /$ iccie.2009.5223811

21. Vafaei N. Data normalisation techniques in decision making: case study with TOPSIS method / N. Vafaei, R. A. Ribeiro, L. M. Camarinha-Matos // International Journal of Information and Decision Sciences - 2018. - Vol. 10, № 1. - P. 19-38. DOI: 10.1504/ijids.2018.090667

22. Alinezhad A. Sensitivity Analysis in the QUALIFLEX and VIKOR Methods / A. Alinezhad, N. Esfandiari // Journal of
Optimization in Industrial Engineering - 2012. - Vol. 6, № 1 (10). - P. 29-34.

23. Muñoz B. Sensitivity Analysis of Multicriteria Decision Making Methodology Developed for Selection of Typologies of Earth-retaining Walls in an Urban Highway / B. Muñoz, M. G. Romana, J. Ordóñez // Transportation Research Procedia - 2016. - Vol. 18. - P. 135-139. DOI: 10.1016/j.trpro.2016.12.019

24. Automotive style design assessment and sensitivity analysis using integrated analytic hierarchy process and technique for order preference by similarity to ideal solution / [G. Tian, H. Zhang, H. Jia et al.] // Advances in Mechanical Engineering - 2016. - Vol. 8, № 5. - P. 1-10. DOI: $10.1177 / 1687814016649885$

25. Web Services Quality Factors Version 1.0, Candidate OASIS Standard 01, October 2012 [Electronic resource]. Access mode: http://docs.oasis-open.org/wsqm/WS-QualityFactors/v1.0/cos01/WS-Quality-Factors-v1.0-cos01.html

26. QWS Dataset v2.0, November 2019 [Electronic resource]. Access https://github.com/qwsdata/qwsdata.github.io/releases

27. Polska O. V. Model of web services quality criteria hierarchy / O. V. Polska, R. K. Kudermetov, N. V. Shcherbak // Вісник Запорізького національного університету. Фізико-математичні науки - 2020. - № 2. - С. 43-51. DOI: $10.26661 / 2413-6549-2020-2-06$

28. Dujmovic J. J. Continuous Preference Logic for System Evaluation / J. J. Dujmovic // IEEE Transactions on Fuzzy Systems - 2007. - Vol. 15, № 6. - P. 1082-1099. DOI: 10.1109/TFUZZ.2007.902041

29. Dujmović, J. Partial absorption function / J. Dujmović // Journal of the University of Belgrade, EE Dept., Series Mathematics and Physics - 1979. -№ 659. - P. 156-163.

30. Polska O. V. The approach for QoS based web service selection with user's preferences / O.V. Polska, R. K. Kudermetov, V. V. Shkarupylo // Наукові праці Донецького національного технічного університету, серія: «Проблеми моделювання та автоматизації проектування» - 2020. - №16. - C. 19-27. DOI: 10.31474/2074-7888-2020-2-19-27

31. A Theoretical Analysis of NDCG Ranking Measures / [Y. Wang, L. Wang, Y. Li et al.] // Learning Theory : 26th annual conference, COLT 2013, Princeton, 12-14 June, 2013 : proceedings. - JMLR.org, 2013. - P. 25-54.

32. Fogli A. Exploiting semantics for context-aware itinerary recommendation / A. Fogli, G. Sansonetti // Personal and Ubiquitous Computing - 2019. - Vol. 23. - P. 215-231. DOI: $10.1007 / \mathrm{s} 00779-018-01189-7$

33. Normalization Techniques Comparison for QoS-based Web Services Selection by LSP Method / [R. Kudermetov, O. Polska, V. Shkarupylo et al.] // Intelligent Data Acquisition and Advanced Computing Systems (IDAACS-SWS) : 5th IEEE International Symposium Smart and Wireless Systems within the Conferences, Dortmund, 17-18 September 2020: proceeding. - IEEE, 2020. - P. 213-216. DOI: 10.1109/idaacs-sws50031.2020.9297098

34. QoS-aware Web-services Ranking: Normalization Techniques Comparative Analysis for LSP Method / [O. Polska, R. Kudermetov, J. A. J. Alsayaydeh et al.] // ARPN Journal of Engineering and Applied Sciences - 2021. - Vol. 16, № 2. - P. 248-254. 